\title{
Thyroglossal Duct Carcinoma: A Case Series and Approach to Management
}

\author{
${ }^{1} \mathrm{John}$ Mathew Manipadam, ${ }^{2}$ Marie Therese Manipadam, ${ }^{3}$ Elsa Mary Thomas, ${ }^{4}$ Rajiv C Michael \\ ${ }^{1}$ Pooja Ramakant, ${ }^{1}$ Deepak Thomas Abraham, ${ }^{5} \mathrm{MJ}$ Paul \\ ${ }^{1}$ Assistant Professor, Department of Endocrine Surgery, Christian Medical College, Tamil Nadu, India \\ ${ }^{2}$ Associate Professor, Department of Pathology, Christian Medical College, Tamil Nadu, India \\ ${ }^{3}$ Assistant Professor, Department of Radiology, Christian Medical College, Tamil Nadu, India \\ ${ }^{4}$ Associate Professor, Department of ENT, Christian Medical College, Tamil Nadu, India \\ ${ }^{5}$ Professor, Department of Endocrine Surgery, Christian Medical College, Tamil Nadu, India
}

Correspondence: John Mathew Manipadam, Assistant Professor, Department of Endocrine Surgery, Christian Medical College Tamil Nadu, India, e-mail: jm_manipadam@yahoo.com

\section{ABSTRACT}

Thyroglossal duct carcinoma (TGDC) is a rare disease with few reported series. No clear consensus exists regarding further management after adequate excision of the cyst, especially the role of total thyroidectomy and postoperative radioiodine therapy. We review our experience of nine cases and the literature to clarify the management of this rare condition. A retrospective study over a period of 10 years was performed using the clinical records from Christian Medical College, Vellore to identify patients with TGDC and to assess the frequency of cases with concomitant papillary carcinoma of the thyroid. The clinical presentation, fine needle aspiration cytology (FNAC), imaging, treatment and follow-up were analyzed. There were a total of nine cases of TGDC with five males. Imaging available in six patients detected a suspicious lesion in four cysts and three thyroid glands. Preoperative FNAC detected atypical cells in two of five cases. Thyroid carcinoma was seen in four (44.4\%) after histopathological evaluation. Ultrasound of the neck and image-guided FNAC of the cyst may be adequate initial investigation for thyroglossal cysts. FNAC by itself is not a good investigation to diagnose TGDC as rate of false-negatives and inadequate specimens were high. Solid components and calcification on imaging were predictive of carcinoma within a thyroglossal cyst in $100 \%$ cases. All patients with TGDC may be offered total thyroidectomy as a simultaneous or staged procedure to address the high incidence of concomitant thyroid foci of cancer. The role of adjuvant therapy is still debatable.

Keywords: Thyroglossal duct carcinoma, Papillary carcinoma thyroid.

\section{INTRODUCTION}

The thyroglossal duct cyst is the most common congenital cyst in the neck, occurring twice as often as branchial cleft abnormalities. ${ }^{1,2}$ It has a prevalence of approximately $7 \%$ in the adult population in a study on 200 adult larynges. ${ }^{3}$ The incidence of carcinoma in thyroglossal duct cysts is less than $1 \% .{ }^{4,5}$ We found only 290 cases of thyroglossal duct carcinomas reported in literature by PubMed search. In a 2004 review of 215 cases, 80\% were papillary carcinoma. ${ }^{4,6}$ Other cancers in decreasing frequency were squamous cell carcinoma, follicular carcinoma, Hürthle cell, insular and rarely anaplastic carcinoma. Medullary carcinoma has not been reported in a thyroglossal cyst. $^{4,7-9}$

The purpose of this paper is to present a case series of thyroglossal duct cyst carcinomas, analyze the clinical and pathological features, to note the rate of concomitant occurrence of carcinoma of the thyroid and to compare with previously reported series, and establish, modify or corroborate appropriate and existing treatment.

\section{MATERIALS AND METHODS}

A retrospective study was performed at the Christian Medical College Hospital, Vellore. The clinical records were reviewed for the period between 2000 and 2010, identifying patients with a histological diagnosis of carcinoma of thyroglossal duct. The clinical course and treatment instituted and follow-up were analyzed. The efficacy of FNAC and imaging in the preoperative diagnosis was studied. The histopathology slides were reviewed.

\section{RESULTS}

In the specified study period, there were nine cases of carcinoma arising in thyroglossal cysts. The male:female ratio of these patients was 5:4. The average age at presentation was 35.66 years (range of 22-48 years). The average duration of the cyst on history was 34.2 months (8-60 months). The clinicopathologic features are summarized in Table 1. Five patients had a preoperative FNAC of the cyst done. Two of these FNACs were reported as inadequate and one case as benign. Only two of the FNACs were reported as atypical and suggestive of neoplasm.

\section{Imaging}

Three patients underwent surgery without imaging. Out of the remaining six who underwent imaging; four had solid components, calcification and heterogeneous lesions in the 
cyst (Fig. 1) while in one, only the thyroid was imaged and the cyst was not imaged; and in the other, the cyst was already removed in another center. Of the two patients with atypical FNACs, one did not have imaging and the other had heterogeneous solid cystic mass with calcifications on imaging. With regard to the thyroid imaging in these six; three were reported as normal thyroid and three had nodules reported in the thyroid. Among the three reported as normal thyroid; one was histopathologically normal thyroid, one patient underwent only Sistrunk's and did not come for follow-up and the third had an occult $2 \mathrm{~mm}$ microcarcinoma in the thyroid. Among the three cases which had nodules reported; one had a histopathologically normal thyroid, one had a papillary carcinoma focus of the same size as imaging, and one had multiple foci of papillary microcarcinoma wherein the imaging picked up only one nodule.

\section{Surgical Treatment}

All nine cases underwent at least a Sistrunk's procedure. Three cases underwent Sistrunk's procedure only. Of these, only one had suspicious cytology and imaging preoperatively. Of the six cases which had thyroidectomy and Sistrunk's procedure (Fig. 2) three had staged thyroidectomy (two of these were referred after Sistrunk's procedure elsewhere). In two cases, the thyroidectomy was done along with Sistrunk's based on calcification and heterogeneous material in the cyst and nodules in the thyroid imaging. One patient had a preoperative diagnosis of carcinoma available from a cervical node biopsy. One of the patients who had a Sistrunk's procedure elsewhere had a partially resected large $6 \mathrm{~cm}$ tumor, and at reoperation in our center, we removed one infiltrated submandibular salivary gland. Modified radical neck dissection was performed only for the patients with involved neck nodes.

Table 1: Clinicopathologic features of case series of TGDC

\begin{tabular}{|c|c|c|c|c|c|c|c|}
\hline S. No. & Age/sex & $\begin{array}{l}\text { Cytology/ } \\
\text { biopsy }\end{array}$ & Imaging & Surgery done & Pathology & $\begin{array}{l}\text { lodine } \\
\text { treatment }\end{array}$ & Follow-up \\
\hline 1 & $39 / F$ & Inadequate & Not done & $\begin{array}{l}\text { Sistrunk's } \\
\text { followed by } \\
\text { total thyroidectomy }\end{array}$ & $\begin{array}{l}\text { Cyst } 12 \mathrm{~mm} \text { PTC, } \\
\text { thyroid }<5 \mathrm{~mm} \\
\text { follicular variant } \\
\text { of papillary } \\
\text { microcarcinoma }\end{array}$ & $\begin{array}{l}\text { RA, WBSX2 } \\
\text { negative }\end{array}$ & $\begin{array}{l}29 \text { months } \\
\mathrm{DF}, \operatorname{Tg} 1.66 \\
<0.1,<0.1\end{array}$ \\
\hline 2 & $40 / F$ & Nil & $\begin{array}{l}\text { Cyst with calcification } \\
\text { and echogenic material, } \\
\text { thyroid with } 16 \mathrm{~mm} \\
\text { lesion at lower pole, } \\
\text { no nodes }\end{array}$ & $\begin{array}{l}\text { Sistrunk's along with } \\
\text { total thyroidectomy }\end{array}$ & $\begin{array}{l}\text { Cyst } 2 \mathrm{~cm} \mathrm{PTC,} \\
\text { thyroid } 1.5 \mathrm{~cm} \\
\text { papillary } \\
\text { carcinoma }\end{array}$ & $\begin{array}{l}\text { RA, WBSX2 } \\
\text { negative }\end{array}$ & $\begin{array}{l}26 \text { months } \\
\text { DF } \\
\text { Tg } 0.91 \\
0.19 \\
0.16\end{array}$ \\
\hline 3 & $35 / \mathrm{M}$ & $\begin{array}{l}\text { CxLN- } \\
\text { Metastatic } \\
\text { papillary } \\
\text { carcinoma, } \\
\text { cyst cytology } \\
\text { inadequate }\end{array}$ & $\begin{array}{l}\text { Cyst not imaged, } \\
\text { normal thyroid }\end{array}$ & $\begin{array}{l}\text { Sistrunk's along with } \\
\text { total thyroidectomy, } \\
\text { right MRND }\end{array}$ & $\begin{array}{l}\text { Cyst } 7 \mathrm{~mm} \text { PTC, } \\
\text { normal thyroid, } \\
\text { one node } \\
\text { positive for tumor }\end{array}$ & $\begin{array}{l}\text { WBSX3 } \\
\text { negative }\end{array}$ & $\begin{array}{l}36 \text { months } \\
\text { DF } \\
\mathrm{Tg}<0.1 \\
0.41 \\
0.74,<0.1\end{array}$ \\
\hline 4 & $39 / \mathrm{M}$ & $\begin{array}{l}\text { Benign } \\
\text { FNAC }\end{array}$ & $\begin{array}{l}\text { Heterogeneous solid } \\
\text { cystic mass with } \\
\text { calcifications, } \\
\text { thyroid with small } \\
\text { nodules in right lobe, } \\
\text { no nodes }\end{array}$ & $\begin{array}{l}\text { Sistrunk's along with } \\
\text { total thyroidectomy }\end{array}$ & $\begin{array}{l}\text { Cyst } 10 \mathrm{~mm} \text { PTC } \\
\text { Normal thyroid }\end{array}$ & $\begin{array}{l}\text { RA, WBSX2 } \\
\text { negative }\end{array}$ & $\begin{array}{l}20 \text { months } \\
\text { USG neck } \\
4 \mathrm{~mm} \text { LN } \\
\mathrm{Tg} 56.38 \\
41.55 \\
53.17,1.52\end{array}$ \\
\hline 5 & 48/M & Nil & Not done & Sistrunk's & Cyst 15 mm PTC & Nil & Nil \\
\hline 6 & $30 / F$ & $\begin{array}{l}\text { Atypical } \\
\text { FNAC }\end{array}$ & $\begin{array}{l}\text { Heterogeneous solid } \\
\text { cystic mass with } \\
\text { calcifications, normal } \\
\text { thyroid, no nodes }\end{array}$ & Sistrunk's & Cyst $18 \mathrm{~mm}$ PTC & Nil & Nil \\
\hline 7 & $22 / F$ & $\begin{array}{l}\text { Atypical } \\
\text { FNAC }\end{array}$ & Not done & Sistrunk's & Cyst 18 mm PTC & Nil & $\begin{array}{l}89 \text { months } \\
\text { DF }\end{array}$ \\
\hline 8 & $35 / \mathrm{M}$ & Nil & $\begin{array}{l}\text { First scan } \\
\text { normal thyroid, } \\
\text { second scan calcified } \\
\text { nodule in left lobe of } \\
\text { thyroid }\end{array}$ & $\begin{array}{l}\text { Post-Sistrunk's at } \\
\text { other center, } \\
\text { total thyroidectomy, } \\
\text { left MRND }\end{array}$ & $\begin{array}{l}\text { Thyroid-multiple } \\
\text { foci of } \\
\text { microcarcinoma, } \\
\text { three nodes } \\
\text { with tumor }\end{array}$ & $\begin{array}{l}\text { RA, } \\
\text { WBSX2 } \\
\text { negative }\end{array}$ & $\begin{array}{l}21 \text { months } \\
\text { DF, Tg } 16.3 \text {, } \\
4.19,0.85 \\
0.129\end{array}$ \\
\hline 9 & $33 / F$ & Nil & $\begin{array}{l}6 \mathrm{~cm} \text { cystic lesion with } \\
\text { solid enhancing } \\
\text { component, } \\
\text { normal thyroid, } \\
\text { no nodes }\end{array}$ & $\begin{array}{l}\text { Attempted Sistrunk's } \\
\text { at other center } \\
\text { Sistrunk's, Completion } \\
\text { total thyroidectomy }\end{array}$ & $\begin{array}{l}2 \mathrm{~mm} \\
\text { microcarcinoma } \\
\text { in right lobe }\end{array}$ & & 1 month DF \\
\hline
\end{tabular}

RA: Remnant ablation; WBS: Whole body scan; Tg: Thyroglobulin; PTC: Papillary thyroid carcinoma; CxLN: Cervical lymph node; TGDC: Thyroglossal duct carcinoma; USG: Ultrasonography; DF: Disease free; MRND: Modified radical neck dissection 


\section{Pathology}

The gross specimen of thyroglossal cyst with hyoid bone was documented by the pathologist in all the cases (Fig. 3). Size of the cyst ranged from 1 to $6 \mathrm{~cm}$ in size. The papillary carcinoma was seen as thickening of the cyst wall or as papillary projections in the luminal aspect (Fig. 4). Papillary carcinoma was the histological type in all nine cases. There was extension into adjacent fibroadipose tissue and/or skeletal muscle in five of nine cases. Of the six cases with thyroidectomy, four had papillary carcinoma in the thyroid; one had a $5 \mathrm{~mm}$ focus of follicular variant of papillary carcinoma, the second had a $1.5 \mathrm{~cm}$ papillary carcinoma, the third had a $2 \mathrm{~mm}$ focus of papillary carcinoma and the fourth case had multiple foci of papillary carcinoma in the left lobe, each less than $1 \mathrm{~cm}$ in size and a normal right lobe. The last patient had lymph node metastases in level III and level $\mathrm{V}$ left cervical region. None had extrathyroidal extension.

\section{Adjuvant Treatment and Follow-up}

The patients who underwent total thyroidectomy and Sistrunk's procedure were followed up between 1 and 89 months (mean 32) with no residual or recurrent malignant disease. All of them underwent a whole body uptake scan; four had iodine ablation for residual thyroid. None had detectable systemic metastasis. The two patients who are lost to follow-up underwent only a Sistrunk's procedure. Thyroglobulin assay was performed in five of six patients with low values in four (range, $<0.1$ to 0.16). One patient had a value of 50 that reduced to 1.52 after remnant ablation and two negative uptake scans. He underwent neck ultrasound as a part of follow-up which showed two insignificant cervical nodes less than $5 \mathrm{~mm}$ in size. Chest X-ray was normal.

\section{DISCUSSION AND CONCLUSION}

Thyroglossal duct cysts are the most common developmental anomaly of the thyroid. Generally they are benign, but in a

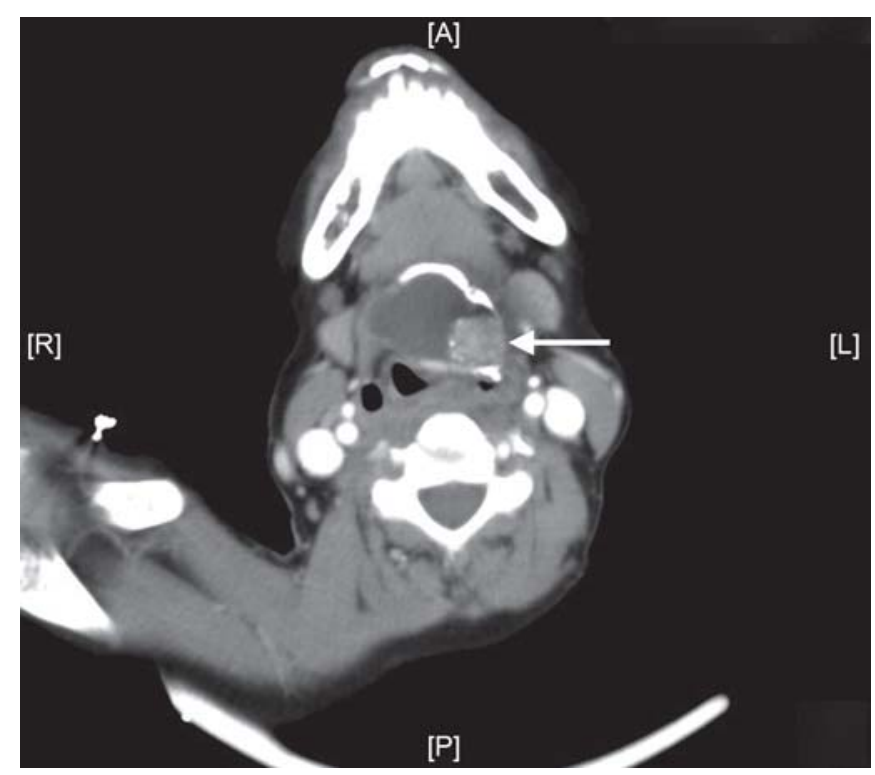

Fig. 1: CECT scan of the neck showing carcinoma in a thyroglossal cyst (arrow)

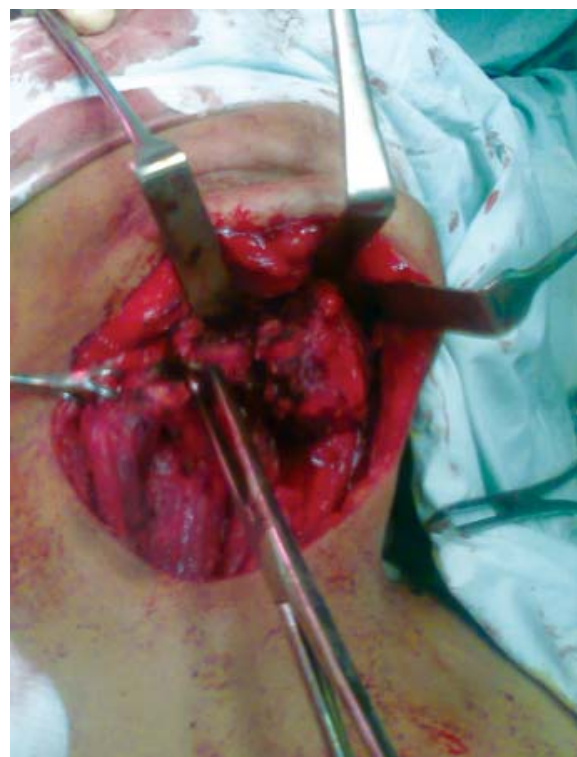

Fig. 2: Intraoperative picture of Sistrunk's procedure for carcinoma of thyroglossal cyst

review of 115 cases, $1 \%$ was reported to develop malignancies. ${ }^{10}$ This figure of $1 \%$ has been quoted elsewhere in literature. ${ }^{7,11,12}$ The commonest malignancy is papillary carcinoma and accounts for 80 to $85 \%$ of cases. ${ }^{5,10,12-14}$ The concomitant occurrence of papillary carcinoma in the thyroglossal cyst and thyroid have also been reported.$^{10}$ In the literature review by Weiss and Orlich, $11.4 \%$ of 115 cases had concomitant carcinoma of the thyroid. In our case series, $44.4 \%$ had concomitant carcinoma in thyroglossal cyst and thyroid. The prognosis for papillary TGDC is excellent, with occurrence of metastatic lesions in less than $2 \%$ of cases. ${ }^{5}$

The median age of presentation of TGDC was 38 years $^{10}$ and ranged from 6 to 84 years. In our study, the average age of presentation was 35.66 years with a range of 22 to 48 years. The female preponderance of 3:2 in published literature ${ }^{10}$ was seen in our series where there was a 5:4 female to male gender ratio.

Barton et al reported that carcinoma should be considered in thyroglossal duct cysts that have a mural nodule or calcification on $\mathrm{CT} .{ }^{15}$ We conclude that solid components and calcification on imaging can predict carcinoma within a thyroglossal duct cyst up to $100 \%$.

The role of FNAC in diagnosing papillary carcinoma in thyroglossal duct cyst has been studied. Published literature quotes a true positive rate of $53 \%$ and a false-negative rate of $47 \% .{ }^{16}$ In a series of cases reviewed by Bardales et al, preoperative diagnosis of malignancy was made in $56 \%$ of cases. ${ }^{17}$ Yang et al attribute the high false-negativity to hypocellularity that results from dilution by the cystic contents. Therefore, it is important to repeat and aspirate any residual solid regions after the cyst has been decompressed. ${ }^{16}$ In our study, the positive rate was $40 \%$ and false-negative rate was $20 \%$. In $40 \%$ of cases where FNA was done, the aspirate was inadequate. In four of the cases, FNA was not done. Hence, we conclude that FNA is useful, but needs careful technical 


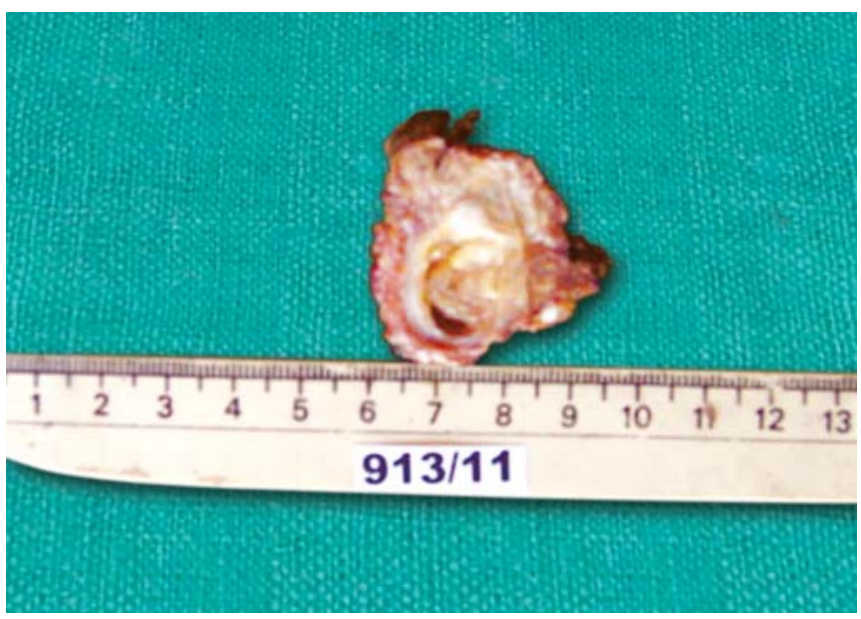

Fig. 3: Cut section of the thyroglossal duct cyst with a tumor projecting into the lumen

performance and is to be interpreted in conjunction with the imaging results.

On histopathological examination, all our cases had papillary carcinoma which is the commonest malignancy reported to arise in thyroglossal duct cysts. ${ }^{13}$ Local extension into adjacent soft tissue or skeletal muscle was seen in more than half (55\%) of the cases. Although soft tissue extension has earlier been reported in malignancies of thyroglossal duct cysts - $20.87 \%$ of a case series by Weiss et al, ${ }^{10}$ whether this has any prognostic impact is not known. ${ }^{18}$ In our series two of the patients who had soft tissue extension had associated thyroid cancer, in two the thyroid was normal, and one patient was lost to follow-up.

There has been no clear consensus in reported literature on the plan of management of these patients. Luna-Oritz et al suggested that once the diagnosis is established by FNAB, imaging studies should be done to evaluate the lateral and central neck nodal metastases and to identify tumor in the thyroid and rule out tumor invasion of surrounding tissues. ${ }^{4}$ Treatment should then be tempered by the patient's age and the size and extent of the tumor. They felt it was difficult to justify anything more than a Sistrunk's procedure for a young person with a small $(<1 \mathrm{~cm})$ tumor confined to a thyroglossal cyst and a sonologically normal thyroid. On the other hand, they noted that certain clinical situations warranted the approach of total thyroidectomy and 131 I therapy; these included older patients, those with invasive or metastatic tumor, histological features that portend a poor prognosis, prior head and neck irradiation or a malignant tumor in the thyroid gland. ${ }^{19}$ Though this concept of therapeutic decision making, based on risk groups, appears attractive, it is felt that there is insufficient data to allow accurate development of risk groups and to allocate relative importance to the various prognostic indices. ${ }^{6}$

In a study by Peretz et al, there was no evidence to show that thyroidectomy improves the prognosis of pediatric patients with a well-differentiated thyroid carcinoma within the thyroglossal duct cyst. ${ }^{20}$

Patel et al in 2002 showed that univariate analysis of prognostic factors predictive of overall survival revealed that

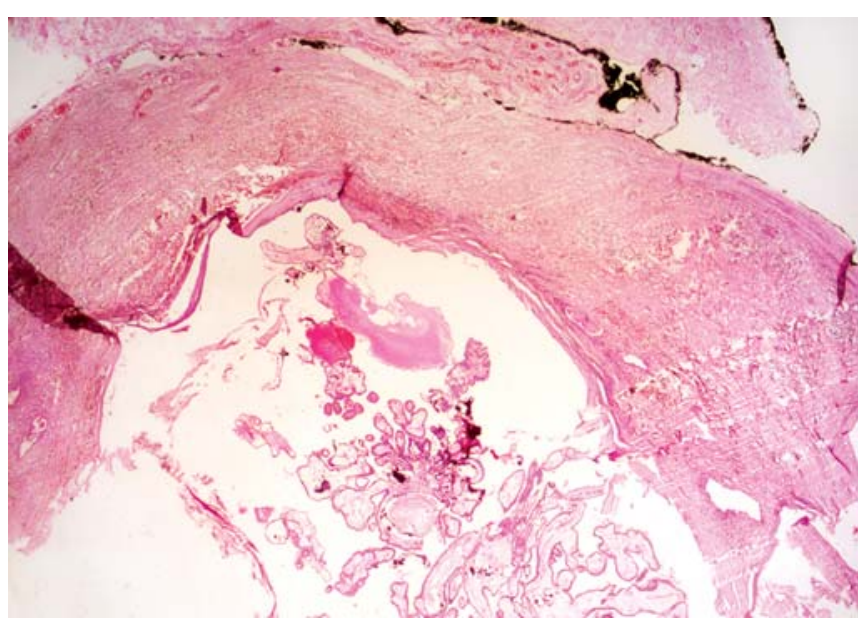

Fig. 4: Microscopy: Scanner magnification, hematoxylin and eosin stain-fibrocollagenous cyst wall with papillary carcinoma

the only significant predictor of outcome was the extent of surgery for thyroglossal cyst. The addition of total thyroidectomy did not have a significant impact on outcome $(\mathrm{p}=0.1){ }^{21}$

Miccoli et al analyzed their series of 18 cases and concluded that total thyroidectomy should always be considered with Sistrunk's procedure to permit the correct treatment and followup in these patients. ${ }^{22}$

In our study, four out of the nine patients (44.4\%) had evidence to point towards concomitant (3 synchronous and one metachronous) occurrence of thyroid carcinoma. Of particular interest is case no. 8 , who had a sonologically normal thyroid at the time of Sistrunk's procedure, but presented a year later with palpable thyroid cancer and metastatic lymph nodes. Additionally, simultaneous thyroidectomy detected a $2 \mathrm{~mm}$ focus of papillary carcinoma that was sonologically occult in case no. 9. This may justify a recommendation for total thyroidectomy with Sistrunk's procedure in all cases with thyroglossal cyst carcinoma even when the thyroid is sonologically normal if it can be performed safely and acceptably with low risk of complications. Information was not available about two patients who underwent Sistrunk's alone. The patients who underwent total thyroidectomy and Sistrunk's procedure are all free of disease till date as all are being followed up for iodine uptake scan and ablation. Two reasons, therefore, emerge to support the recommendation for simultaneous or staged thyroidectomy in cases of TGDC even though survival benefit is unlikely. One is the high incidence of concomitant thyroid cancers and the other is the fact that they may be sonologically occult. Total thyroidectomy may therefore be advised for the same reasons it is done in unilateral thyroid cancers - removes the risk of recurrence and permits systemic evaluation, treatment and follow-up using serum markers. Clinical experience may be inaccurate leading to over or under-treatment in these patients. Molecular analysis may be required to stratify cases that may truly benefit from this recommendation.

There is no role for elective neck dissection in patients with no neck nodes in TGDC. ${ }^{6}$ Our conclusion is that lymph node 
dissection may be reserved for patients with palpable or sonologically abnormal neck nodes.

\section{REFERENCES}

1. Allard RHB. The thyroglossal duct. Head and Neck Surg 1982;5:134-36.

2. Trail ML, Zeringue GP, Chicola JP. Carcinoma in thyroglossal duct remnants. Laryngoscope 1977;87:1685-91.

3. Ellis PD, Van Nostrand AW. The applied anatomy of thyroglossal tract remnants. Laryngoscope 1977;87:765-70.

4. Luna-Oritz, Hurtado Lopez, Valderrama-Landaeata, Ruiz vega. Thyroglossal duct cyst with papillary carcinoma: What must be done? Thyroid 2004;14(5).

5. Park M, Yoon J, Jegal Y, Lee J. Papillary thyroglossal duct cyst carcinoma with synchronous occult papillary thyroid microcarcinoma. Yonsei Med J 2010;51(4):609-11.

6. Cherian MP, Nair B, Thomas S, Somanathan T, Sebastian P. Synchronous papillary carcinoma in thyroglossal duct cyst and thyroid gland: Case report and review of literature. Head Neck 2009;31(10):1387-91.

7. Kennedy Thomas L, Whitaker Mark, Wadih George. Thyroglossal duct carcinoma: A rational approach to management. The Laryngoscope 1998;108:1154-58.

8. Mobini J, Krouse TB, Klinghoffer JF. Squamous cell carcinoma arising in a thyroglossal duct cyst. Am Surg 1974;40:290-94.

9. Livolsi VA, Perzin KH, Savetsky L. Carcinoma arising in median ectopic thyroid (including thyroglossal duct tissue). Cancer 1974;34:1303-15.

10. Weiss SD, Orlich CC. Primary papillary carcinoma of thyroglossal duct cyst: Report of a case and literature review. Br J Surg 1991;78:87-89.

11. Topf P, Fried MP, Strome M. Vagaries of thyroglossal duct cysts: Laryngoscope 1988;98:740-42.
12. Larouere MJ, Drake AF, Baker SR, Richter HJ, Magielski JE. Evaluation and management of a carcinoma in a thyroglossal duct cyst. Am J Otolaryngol 1987;8:351-55.

13. Joseph TH, Komorowski RA. Thyroglossal duct carcinoma. Hum Pathol 1975;6:717-29.

14. Chandran BS, Raman A, Perakath B, Subhashini J, Nair A. Primary papillary carcinoma in a thyroglossal cyst. JAPI 2001;49:283.

15. Barton F, Branstetter, Jane L Weissman, Thomas L Kennedy, Whitaker Mark. The CT appearance of thyroglossal duct carcinoma. AJNR Am J Neuroradiol 2000;21:1547-50.

16. Yang YJ, Haghir S, Wanamaker JR, Powers CN. Diagnosis of papillary carcinoma in a thyroglossal duct cyst by fineneedle aspiration biopsy. Arch Pathol Lab Med 2000;124: 139-42.

17. Bardales RH, Suhrland MJ, Korourian S, Schaefer RF, Hanna EY, Stanley MW. Cytologic findings in thyroglossal duct carcinoma. Am J Clin Pathol 1996;106:615-19.

18. Basu S, Shet T, Borges AM. Outcome of primary papillary carcinoma of thyroglossal duct cyst with local infiltration into soft tissue and uninvolved thyroid. Ind J Cancer 2009;46(2): 169-70.

19. Mazzaferi Ernest L. Guest editorial. Thyroid cancer in thyroglossal duct remnants: A diagnostic and therapeutic dilemma. Thyroid 2004;14(5).

20. Peretz Asaf, Leiberman Esther, Kapelushnik Joseph, Hershkovitz Eli. Thyroglossal duct carcinoma in children: Case presentation and review of the literature. Thyroid 2004;14(9).

21. Patel SG, Escrig M, Shaha AR, Singh B, Shah JP. Management of well-differentiated thyroid carcinoma presenting within a thyroglossal duct cyst. J Surg Oncol 2002;79:134-39.

22. Miccoli Paolo, Minuto Michelle N, Galleri David, Puccini Marco, Berti. Extent of surgery in thyroglossal duct carcinoma: Reflections on a series of 18 cases. Thyroid 2004;14(2).

\section{Erratum}

In the Case Report (Title-Incidental Finding of Composite Pheochromocytoma-Ganglioneuroma: Successful Management after Emergent Appendectomy and Review of the Literature) of issue January-April 2011 Vol. 3 No. 1 the city name Lowa be read as Iowa, under the affiliations segment. 